\title{
KEMAMPUAN MENYIMAK WACANA DESKRIPSI SISWA KELAS V SD ALKHAIRAAT I PALU
}

\author{
Mardiah \\ Program Studi Bahasa dan Sastra Indonesia, Fakultas Sastra, Universitas Alkhairaat \\ mardiah@gmail.com
}

\begin{abstract}
ABSTRAK
Tujuan penelitian ini adalah (1) Untuk mendeskripsikan kemampuan siswa kelas V SD Alkhairaat I Palu dalam menyimak wacana deskripsi. (2) Untuk mendeskripsikan faktor-faktor yang menjadi kendala dan solusi pada pelaksanaan menyimak wacana deskripsi siswa kelas V SD Alkhairaat I Palu. Penulis memilih judul penelitian ini karena pembelajaran menyimak merupakan suatu keterampilan yang sangat penting untuk meningkatkan daya nalar siswa dalam semua bidang studi, khususnya bidang studi Bahasa Indonesia. Penelitian ini menggunakan metode deskriptif dengan teknik pengumpulan data observasi, wawancara, perekam, kuesioner dan evaluasi, hasil akhir peneliti menunjukkan bahwa nilai rata-rata 82 yang diperoleh siswa kelas V SD Alkhairaat I Palu dalam menyimak wacana deskripsi termasuk kategori nilai cukup baik.
\end{abstract}

Kata Kunci : Menyimak, Wacana Deskripsi.

\begin{abstract}
The purpose of this study is (1) To describe the ability of Grade V students of SD Alkhairaat I Palu in listening to description discourse. (2) To describe the factors that become obstacles and solutions in the implementation of listening to the discourse description of the fifth grade students of SD Alkhairaat I Palu. The author chose the title of this research because listening learning is a very important skill to improve students' reasoning power in all fields of study, especially in the area of Indonesian Language studies. This study uses a descriptive method with data collection techniques of observation, interviews, recorders, questionnaires and evaluations, the final results of the researchers showed that the average value of 82 students obtained grade V SD Alkhairaat I Palu in listening to the discourse description including the category category of grades is quite good.
\end{abstract}

Keywords : Listening, Description discourse

\section{PENDAHULUAN}

Dalam sistem pendidikan nasional, mata pelajaran Bahasa Indonesia adalah bagian dari mata pelajaran yang diwajibkan untuk diajarkan di sekolah mulai dari tingkat TK, SD, SMP, dan SMA bahkan perguruan tinggi. Di dalam pembelajaran Bahasa Indonesia terdapat empat keterampilan berbahasa yaitu keterampilan menyimak, keterampilan berbicara, keterampilan membaca, dan keterampilan menulis. Keempat keterampilan berbahasa tersebut jika dikuasai dengan benar maka akan melahirkan penguasaan bahasa itu sendiri secara baik dan benar, sebab semua keterampilan itu saling kait mengait antara satu dengan lainnya.

Dalam memperoleh keterampilan berbahasa, sangat erat hubungannya dengan proses berfikir sebagai bagian yang mendasari bahasa. "Bahasa seseorang mencerminkan pikirannya, semakin terampil seseorang berbahasa, semakin cerah dan jelas pula pikirannya. Keterampilan hanya dapat diperoleh dan dikuasai dengan jalan praktek dan latihan. Melatih keterampilan berbahasa 
berarti melatih keterampilan berfikir. Dawson dalam Tarigan (1989: 3).

Keterampilan menyimak bagi siswa yang termuat dalam kurikulum ditujukan pada keterampilan mendengar, memahami, menginterprestasikan, mengevaluasi dan menanggapi, sehingga fungsi pembelajaran menyimak lebih ditujukan pada bentuk performansi dari pada sebagai sebuah sistem ilmu. Untuk menanamkan keterampilan menyimak dalam pengajaran Bahasa Indonesia, maka langkah-langkah itu meliputi : identitas mata pelajaran, perumusan standar kompetensi dan kompetensi dasar; penentuan indikator, penilaian yang meliputi jenis tagihan, bentuk instrument, dan contoh instrument ; perkiraan waktu yang dibutuhkan; pemilihan sumber/ bahan/ alat. (Ditjen Dikdasmen. Depdiknas, 2004: 5).

Dari uraian tersebut penulis mengembangkan kajian penelitian mengenai "Kemampuan Menyimak Wacana Deskripsi Siswa Kelas V SD Alkhairaat I Palu", dengan menggunakan kurikulum berbasis kompetensi. Penulis melihat perlunya suatu penelitian yang terfokus pada masalah menyimak wacana di sekolah tersebut, hal ini didasarkan atas beberapa pertimbangan :

a. Bahwa menyimak wacana deskripsi baru dilakukan oleh penulis sendiri di SD Alkhairaat I Palu.

b. Penulis termotivasi untuk melakukan studi keterampilan menyimak wacana, mengingat pelajaran menyimak merupakan suatu keterampilan yang sangat penting untuk meningkatkan daya nalar dalam semua bidang studi, khususnya bidang studi Bahasa Indonesia, dan juga keterampilan menyimak merupakan keterampilan yang teratas dari ketiga keterampilan lainnya yaitu keterampilan berbicara, keterampilan membaca, dan keterampilan menulis.

\section{METODE PENELITIAN}

Metode yang digunakan pada penelitian ini adalah metode deskriptif. Metode deskriptif adalah metode yang digunakan memaparkan serta menganalisis ata berdasarkan fakta-fakta yang tampak atau sebagaimana adanya (Soejono, 1999 : 23). Oleh karena itu penggunaan metode deskriptif dalam penelitian ini angat tepat, dengan tujuan untuk mendapat gambaran yang jelas, mengenai masalah yang diteliti dan dianalisis tentang Kemampuan Siswa Kelas V SD Alkhairaat I Palu dalam Menyimak Wacana Deskripsi. Untuk mendapat data yang akurat dan relevan dengan tujuan penelitian, maka dilakukan pengambilan data dengan teknik observasi, wawancara, dan perekam. Adapun metode yang digunakan menganalisis data penelitian ini adalah metode deskriptif kualitatif. Seperti yang dijelaskan Hubermen (1992 : 16) bahwa analisis terdiri dari tiga alur kegiatan yaitu reduksi data, penyajian data, dan penarikan kesimpulan/verifikasi.

\section{HASIL DAN PEMBAHASAN}

Setelah melakukan proses penelitian, diperoleh data tentang Kemampuan Siswa Kelas V SD Alkhairaat I Palu dalam Menyimak Wacana Deskripsi. Data yang dimaksud adalah (1) hasil observasi terhadap guru, (2) hasil evaluasi pembelajaran.

Untuk Kemampuan guru melaksanakan kegiatan pembelajaran bapegang pada keterampilan dasar guru yang terdiri atas 9 komponen. Sembilan komponen tersebut akan dinilai dengan kriteria sebagai berikut :

A : Apabila kemampuannya baik (proses pembelajaran melibatkan siswa secara keseluruhan berperan aktif dan kreatif).

B : Apabila kemampuannya cukup (siswa yang melakukan pembelajaran tidak keseluruhan berperan aktif dan kreatif, melainkan hanya setengah dari keseluruhan siswa yang berperan aktif dan kreatif).

C : Apabila kemampuannya kurang (proses pembelajaran tidak berjalan dengan baik)

Berdasarkan penelitian yang dilakukan, diperoleh gambaran tentang pelaksanaan pembelajaran bahasa Indonesia pada fokus menyimak, bahwa guru telah memiliki, menguasai dan mampu mengoperasikan kemampuan dalam melakukan tugasnya sebagai guru. Data menunjukkan bahwa dari 9 kemampuan yang diamati, tidak satupun yang dinilai kurang, sementara yang dinilai baik adalah membuka pelajaran, menjelaskan materi, mengadakan 
variasi, penguasaan kelas, dan menutup pelajaran. Sedangkan yang dinilai cukup adalah memberi penguatan, mengajukan pertanyaan/bertanya, membimbing diskusi, memacu kemampuan mengingat, dan memahami materi. Secara rinci, data tersebut dapat dilihat pada table berikut.

Tabel 1. Keterampilan Dasar Guru Bahasa Indonesia Mengajar di Kelas V SD Alkhairaat I Palu

\begin{tabular}{clccc}
\hline No & Komponen Ketrampilan Mengajar & A & B & C \\
\hline 1. & Membuka pelajaran & $\sqrt{ }$ & & \\
2. & Menjelaskan materi/mengguna-kan & $\sqrt{ }$ & & \\
& media & & & \\
3. & Memberi penguatan & & $\sqrt{ }$ & \\
4. & Mengadakan variasi & $\sqrt{ }$ & & \\
5. & Mengajukan pertanyaan/bertanya & & $\sqrt{ }$ \\
6. & Membimbing diskusi & & $\sqrt{ }$ \\
7. & Memacu kemampuan mengingat dan & & $\sqrt{ }$ \\
& memahami materi & & & \\
8. & Penguasaan kelas & $\sqrt{ }$ & & \\
9. & Menutup pelajaran & $\sqrt{ }$ & \\
\hline
\end{tabular}

Kemampuan guru menguasai

keterampilan dasar dalam melaksanakan pembelajaran jelas akan mempengaruhi kegiatan proses pembelajaran sekaligus mempengaruhi hasil belajar siswa.

Hasil penilaian tentang kegiatan yang terjadi selama proses pembelajaran dapat dilihat pada tabel 2, komponen-komponen yang perlu diamati sangat banyak, namun yang dideteksi hanya dua puluh komponen sesuai format pengamatan yang telah dibuat yang mengacu pada karakteristik komponen kegiatan proses pembelajaran yang dilaksanakan dengan strategi CTL yang dijelaskan Endah (2002 : 1).

Pengamatan dilakukan dengan memberi tanda cek $(\sqrt{ })$ pada jawaban ya atau tidak, dengan ketentuan apabila komponen kegiatan dilakukan, atau terjadi, atau tergambar maka jawabnya ya, sebaliknya jika komponen kegiatan tidak dilakukan, tidak terjadi, atau tidak tergambar maka jawabannya tidak. sebagai berikut:

Tabel 2. Data Pengamatan Kegiatan Selama Proses Pembelajaran

\begin{tabular}{|c|c|c|c|}
\hline No & Komponen Kegiatan Proses Belajar Mengajar dengan Strategi CTL & & B \\
\hline 1. & Pengolahan kelas dilakukan dengan baik & $\sqrt{ }$ & \\
\hline 2. & $\begin{array}{l}\text { Sebelum melakukan pembelajaran guru sudah mempersiapkan silabus } \\
\text { pembelajaran. }\end{array}$ & $\sqrt{ }$ & \\
\hline 3. & Pembelajaran dilaksanakan dalam konteks yang ontetik & $\sqrt{ }$ & \\
\hline 4. & $\begin{array}{l}\text { Pembelajaran memberikan kesempatan kepada siswa untuk mengerjakan tugas- } \\
\text { tugas yang bermakna (meaningful learning). }\end{array}$ & $\sqrt{ }$ & \\
\hline 5. & $\begin{array}{l}\text { Pembelajaran dilaksanakan melalui kerja kelompok, berdiskusi, saling } \\
\text { mengoreksi (learning in a group) }\end{array}$ & $\sqrt{ }$ & \\
\hline 6. & Pembelajaran dilaksanakan secara aktif, kreatif, produktif. & $\sqrt{ }$ & \\
\hline 7. & Waktu digunakan secara efisien sesuai dengan alokasi. & $\sqrt{ }$ & \\
\hline 8. & Kegiatan sesuai dengan tujuan, materi dan situasi. & $\sqrt{ }$ & \\
\hline 9. & Uraian kegiatan sistematis dan logis. & $\sqrt{ }$ & \\
\hline 10. & Petunjuk dan penjelasan materi terorganisir. & $\sqrt{ }$ & \\
\hline 11. & Respon dan pertanyaan siswa disahuti dan dijawab. & $\sqrt{ }$ & \\
\hline 12. & Ekspresi lisan dan tulisan mudah ditangkap siswa. & $\sqrt{ }$ & \\
\hline 13. & Mendemonstrasikan kemampuan mengajar dan metode bervariasi secara luwes. & $\sqrt{ }$ & \\
\hline 14. & $\begin{array}{l}\text { Membantu siswa mengenal maksud dan pentingnya tema dan sub tema/topik } \\
\text { pembahasan. }\end{array}$ & $\sqrt{ }$ & \\
\hline
\end{tabular}




\begin{tabular}{llcl}
\hline 15. & Penguasaan bahan materi & $\sqrt{ }$ \\
16. & Pada awal pembelajaran melibatkan siswa secara aktif & $\sqrt{ }$ \\
17. & Melibatkan siswa secara penuh untuk berpartisipasi & & $\sqrt{ }$ \\
18 & Melaksanakan penilaian proses pembelajaran. & $\sqrt{ }$ \\
19. & Melaksanakan penilaian akhir pembelajaran. & $\sqrt{ }$ \\
20. & Tampil sungguh-sungguh sebagai guru yang baik & $\sqrt{ }$ \\
\hline
\end{tabular}

Dari dua puluh komponen yang diamati, sembilan belas terlaksana, terjadi dan tergambar, sementara yang tidak terlaksanakan hanya satu komponen yaitu penilaian proses pembelajaran. Pembelajaran yang seperti ini akan membuahkan hasil yang baik, namun baru dilihat dari dua sisi yaitu keterampilan dasar dan kegiatan pembelaiaran yang dilakukan oleh guru, masih ada lagi penilaian yang lain yaitu metode dan media yang digunakan gm dalam melakukan pembelajaran serta siswa yang menjadi objek utama penelitian dan kuesioner yang ditujukan kepada guru.
Metode yang digunakan oleh guru dalam melakukan pembelajaran menyimak wacana adalah metode diskusi, ceramah dan Tanya jawab, serta menggunakan media, buku teks, kaset yang berisikan rekaman suatu wacana yang akan disimak oleh siswa.

Mengenai lembar obsevasi yang memuat tentang pelaksanaan "guru dalam melakukan proses pembelajaran menyimak wacana dengan menggunakan pendekatan kontekstual dilakukan oleh guru. Untuk lebih jelasnya dapat dilihat pada tabel 3 sebagai berikut.

Tabel 3. Pelaksanaan Kegiatan Guru dalam Melakukan Pembelajaran Menyimak Wacana

\begin{tabular}{|c|c|c|c|c|c|c|}
\hline No & $\begin{array}{c}\text { Jam } \\
\text { Pelajaran }\end{array}$ & $\begin{array}{l}\text { Nama } \\
\text { Guru }\end{array}$ & Kelas & Materi & Kegiatan & Keterangan \\
\hline 1. & $1-2$ & Nurhayati & V & Menyimak & $\begin{array}{l}\text { Proses } \\
\text { belajar } \\
\text { mengajar }\end{array}$ & $\begin{array}{l}\text { Menggunakan } \\
\text { pendekatan } \\
\text { kontekstual. } \\
\text { Menggunakan } \\
\text { prinsip dasar CCTL: } \\
\text { 1. Inquiry } \\
\text { 2. Konstruktivis-me } \\
\text { 3. Bertanya } \\
\text { (questioning) } \\
\text { 4. Modeling } \\
\text { (permodelan) } \\
\text { 5. Masyarakat } \\
\text { belajar/learning } \\
\text { community } \\
\text { 6. Reflection } \\
\text { 7. Authentic } \\
\text { Assesment }\end{array}$ \\
\hline
\end{tabular}

CTL sebagai berikut :

1. Inquiry adalah pengamatan untuk memahami konsep dan fenomena yang terjadi secara alamiah.

2. Konstruktivisme adalah pembelajaran yang menekankan terbangunnya pemahaman sendiri secara aktif, kreatif dan produktif.
3. Bertanya (questioning) adalah kegiatan guru untuk mendorong siswa mengetahui sesuatu, mengarahkan untuk memperoleh informasi membimbing dan menilai kemampuan berpikir siswa.

4. Modeling adalah kegiatan pemberian model dengan tujuan untuk membahasakan gagasan yang kita pikirkan. 
5. Learning community adalah kegiatan pembelajaran yang difokuskan pada aktivitas berbicara dan berbagi pengalaman dengan orang lain.

6. Reflection adalah kegiatan memikirkan apa yang telah kita pelajari menelaah dan merespon semua kejadian, aktivitas, serta memberikan masukan-masukan yang berguna.

7. Authentic Assesment adalah mengukur pengetahuan dan ketrampilan siswa, tugas-tugas yang diberikan harus kontekstual dan relevan, penilaian bersifat terbuka, jujur/objektif.

Berdasarkan hasil evaluasi yang dilakukan dalam penelitian telah diperoleh nilai variabel siswa kelas V SD Alkhairaat I Palu dalam melakukan penyimakan wacana deskripsi.

Kriteria yang digunakan untuk mengklasifikasikan hasil evaluasi siswa berupa skor, akan diurutkan pengelolaan skor mentah menjadi nilai.

Adapun rumus yang digunakan untuk menghitung skor mentah hasil tes setiap orang siswa, sebagai berikut :

$$
\text { Mean : } \frac{\text { Skor total }}{\text { Skor Maksimum }} \times 100
$$

Penentuan peringkat digunakan kriteria penilaian sebagai berikut :

1. Angka $95-100=$ sangat baik
2. Angka $85-94=$ baik

3. Angka $75-84=$ cukup

4. Angka $<75=$ kurang

Bila menentukan peringkat keberhasilan siswa dalam melakukan penyimakan wacana, atas dasar persentase adalah:

1. Siswa dinyatakan berhasil bila mencapai 76,00 atau lebih.

2. Siswa dinyatakan gagal bila mencapai 75;00 ke bawah.

Dari hasil penelitian, diperoleh variasi skor, yaitu yang memperoleh skor 48 sebanyak 1 orang, skor 44 sebanyak 5 orang, skor 42 sebanyak 1 orang, skor 40 sebanyak 9 orang, skor 38 sebanyak 7 orang. Rincian skor tersebut menunjukkan bahwa:

1) Skor tertinggi adalah 48 dengan frekuensi 1 orang

2) Skor terendah adalah 38 dengan frekuensi 7 orang

Setelah mengetahui skor setiap siswa, maka skor tersebut dijadikan nilai dengan skala 0100. Berdasarkan hasil konversi nilai akir perolehan siswa kelas V SD Alkhairaat I Palu pada menyimak wacana deskripsi diperoleh nilai rata-rata 82 . Nilai 82 telah melebihi 75,00 yang dijadikan standar keberhasilan, hal ini menunjukkan kemampuan siswa pada kategori cukup baik dan menghampiri baik. Untuk lebih jelasnya dapat dilihat tabel analisis hasil belajar di bawah ini:

Tabel 4. Nilai Hasil Evaluasi Siswa dalam Melakukan Penyimakan Wacana Deskripsi di Kelas V SD Alkhairaat I Palu

\begin{tabular}{cccc}
\hline No & Nilai & Frekuensi & Persentase \\
\hline 1 & $85-100$ & 3 & 13 \\
2 & $75-84$ & 20 & 87 \\
& Jumlah & 23 & 100 \\
\hline
\end{tabular}

\section{KESIMPULAN}

Berdasarkan hasil analisis, diperoleh gambaran ada nilai 76 sebanyak 4 orang. Nilai 80 sebanyak 11 orang, nilai 84 sebanyak 5 orang, nilai 88 sebanyak 1 orang, nilai 92 sebanyak 1 orang dan 96 sebanyak 1 orang. Dengan demikian dapat disimpulkan bahwa siswa kelas V SD Alkhairaat I Palu berhasil cukup baik dalam menyimak wacana deskripsi dengan nilai rata-rata 80 tersebut termasuk kategori baik dan persentase ketuntasan $100 \%$.

\section{DAFTAR PUSTAKA}

Ahmad, Tafsir. (1998). Metode Pengajaran. Bandung : Remaja Rosda Karya.

Badru, Syahidin dkk. (2003). Pemahaman dan Penguasaan Siswa Terhadap 
Wacana Bahasa Indonesia. Jakarta : Pusat Bahasa.

Departemen Pendidikan dan Kebudayaan. (1991). Kamus Besar Bahasa Indonesia. Jakarta. Edisi kedua. Jakarta : Departemen Pendidikan dan Kebudayaan. Balai Pustaka.

Guntur Tarigan, Hendri. (1989). Menyiniak Sebagai Suatu Keterampilan Berbahasa. Jakarta, Penerbit Angkasa.

Guntur Tarigan, Hendri. (1987). Pengajaran Wacana. Bandung : Penerbit Angkasa.

Mulyana, M.Hum. (2005). Kajian Wacana. Yogyakarta : Tiara Wacana.
Mukayat, D. Brotowidjoyo. (1993). Penulisan Karangan Ilmiah. Jakarta : Akademika Pressindi.

Samsuri. (1988). Analisis Wacana. Malang : Pengembangan Perguruan Tinggi.

Soejono. (1997). Metode Penelitian Suatu Pemikiran dan Penerapan. Bandung : Rineka Citra.

Umar, Husein. (2001). Metode Penelitian Untuk Skripsi dan Bisnis. Jakarta : P.T Raja Grafindo Persada. 